\title{
KEBUTUHAN MAHASISWA TERHADAP BAHAN AJAR DI ERA PANDEMI
}

Student's Needs for Teaching Materials in the Era of Pandemic

\author{
Lira Hayu Afdetis Mana \\ STKIP PGRI Sumatera Barat \\ lirahayuam@gmail.com
}

\begin{abstract}
Abstrak
Penelitian ini bertujuan untuk menganalisis kebutuhan mahasiswa terhadap bahan ajar di era pandemi covid 19. Subjek dalam penelitian ini adalah mahasiswa STKIP PGRI Sumbar yang. Data pada penelitian ini diperoleh dari hasil angket analisis kebutuhan mahasiswa terhadap bahan ajar di era pandemi covid 19 melalui google form yang telah disediakan peneliti untuk mengetahui tanggapan-tanggapan mahasiswa mengenai bahan ajar yang diperoleh selama ini. Hasil penelitian dari analisis kebutuhan mahasiswa terhadap bahan ajar yaitu: pertama, mahasiswa membutuhkan bahan ajar yang disediakan oleh dosen dari e-learning. kedua, mahasiswa lebih cepat memahami sebuah bahan ajar jika bahan ajar tersebut diberikan oleh dosen melalui e-learning lalu mengunduh dan memprintnya. ketiga, mahasiswa lebih menyukai tampilan power point yang lengkap disertai penjelasan dosen, keempat, mahasiswa menyukai penggunaan gaya bahasa baku, namun tidak kaku dari sebuah bahan ajar. kelima, bahan ajar yang diberikan dosen saat pembelajaran daring selama ini cukup memenuhi kebutuhan namun belum maksimal, keenam, bahan ajar yang diberikan dosen saat pembelajaran daring cukup relevan/sesuai dengan topik, ketujuh, kebutuhan mahasiswa terhadap bahan ajar sangat tinggi. Ini menunjukkan bahwa mahasiswa membutuhkan informasi yang lebih detail tentang pelajaran dalam rangka mendapatkan pemahaman yang mendalam.
\end{abstract}

Kata kunci : mahasiswa, bahan ajar, Covid 19.

\begin{abstract}
Teaching materials are one of the important components needed in the learning process. With the appropriate teaching materials, it is hoped that it can help the smooth running of learning activities. Likewise with teaching materials in this Pandemic Era. Teaching materials that have been used in learning activities are simple teaching materials made by lecturers. This study aims to analyze student needs for teaching materials in the era of the COVID-19 pandemic, at STKIP PGRI West Sumatra. The subjects in this study were 106 students of STKIP PGRI West Sumatra. The data in this study were obtained from the results of a questionnaire on the analysis of student needs for teaching materials in the Covid 19 pandemic era through the google form that has been provided by researchers to find out student responses regarding the teaching materials that have been obtained so far. The results of the research from the analysis of student needs for teaching materials are: first, students need teaching materials provided by lecturers from e-learning. Second, students understand a teaching material more quickly if the teaching material is provided by the lecturer through e-learning then download and print it. third, students prefer a power point display that is complete with lecturers' explanations. fourth,
\end{abstract}


students like the use of a standard language style, but not rigid of a teaching material. Fifth, the teaching materials that have been given by lecturers during online chasing are sufficient to meet the needs but not maximally, sixth, the teaching materials provided by lecturers during online learning are quite relevant / in accordance with the topic, seventh, the need for students for teaching materials is very high. This shows that students need more detailed information about the lesson in order to gain a deep understanding.

Keywords: Needs Analysis, Students, Teaching Materials, Covid 19.

How to Cite: Mana, Lira Hayu Afdetis. (2021). Kebutuhan Mahasiswa terhadap Bahan Ajar di Era Pandemi. Ranah: Jurnal Kajian Bahasa. 10(1). 110-118. doi: https://doi.org/10.26499/rnh.v10i1.3651

\section{PENDAHULUAN}

Pada masa pandemi banyak ragam penawaran alternatif aplikasi pembelajaran online kian laku di kalangan kaum intelek yang mengharuskan penguasaan teknologi secara seimbang. Mustofa dkk (2019) berpendapat bahwa tidak hanya mahasiswa, namun juga dosen yang harus lebih cakap dalam penguasaan teknologi secara maksimal dengan metode pembaharuan yang layak. Hasil survey menggunakan kuesioner di IAIN Tulungagung dengan sampel pengisian dari seluruh mahasiswa jurusan Ilmu Hadist, terdapat $80 \%$ responden menunjukkan meskipun telah tersedia berbagai fasilitas pembelajaran basis online tetap tidak efektif dalam sistem pembelajaran, banyak mahasiswa milenial lebih menyukai perkuliahan offline dari pada online.

Marbun (2021) mengatakan bahwa pengaruh covid-19 tidak bisa dipungkiri telah mengubah konsep, metode dan desain pembelajaran yang ada. Rusdiana dkk (2020) menjelaskan bahwa masa covid 19 merubah pembelajaran konvensional, salah satu diantaranya guru, dosen dan anak didik harus terbiasa dengan pembelajaran daring. Dalam penelitian Rusdiana disebutkan bahwa masa covid-19 secara luas mendorong dosen menerapkan pola pembelajaran student center learning. Pembatasan perjumpaan dosen dengan mahasiswa mengharuskan kreativitas dan inovatif dalam mendesain pola pembelajaran.

Masa Pandemi Covid-19 yang masih berlanjut membuat kita mengubah berbagai kebiasaan yang sering disebut dengan istilah New Normal, dalam aktivitas sehari-hari dan aktivitas pembelajaran. STMIK Profesional Makassar juga mengubah kebiasaan belajar dari tatap muka menjadi daring. Mahasiswa kadang jenuh jika belajar secara daring, hanya sekedar hadir dan menunggu berakhirnya pembelajaran (Mallu \& Samsuriah, 2020). Beberapa penelitian tersebut dapat dilihat bahwa pembelajaran di Era pandemi ini telah mengubah konsep, metode, desain pembelajaran. Namun, pada penelitian ini berdasarkan analisis kebutuhan mahasiswa terhadap bahan ajar, maka perlu adanya perbaikan terhadap bahan ajar yang diberikan oleh dosen.

Bahan ajar adalah segala bentuk bahan yang digunakan untuk membantu guru/instruktur dalam melaksanakan kegiatan belajar mengajar di kelas (Prastowo, 2012). Bahan yang dimaksud bisa berupa bahan tertulis maupun bahan tidak tertulis. Secara garis besar bahan ajar terdiri atas dua jenis, yaitu bahan ajar cetak dan bahan ajar noncetak. Contoh bahan ajar cetak adalah buku teks, buku ajar, handout, modul, poster, dan leaflet, sedangkan bahan ajar noncetak dapat berupa bahan ajar audio seperti kaset, radio, bahan ajar visual seperti gambar, foto, maupun bahan ajar audiovisual seperti video/film. Bahan ajar merupakan salah satu komponen yang memegang peranan penting dalam proses pembelajaran. Menurut Ardiansyah dkk (2016) bahan ajar merupakan salah satu komponen yang dapat membantu kelancaran belajar siswa maupun mahasiswa. Bahan ajar merupakan bahan yang dipersiapkan dan dibawa guru untuk menyampaikan materi pembelajaran. 
Penelitian relevan yang pernah dilakukan adalah penelitian Libiawati dkk (2020) yang berjudul "Analisis Kebutuhan Penyusunan Buku Ajar Pembelajaran Bahasa Indonesia Berbasis Menulis Teks Eksplanasi". Hasil penelitian tersebut menunjukkan bahwa bahan ajar memang diperlukan sebagai efektivitas dalam kegiatan pembelajaran. Hal ini menjadi dasar dalam penyusunan buku ajar pada mata pelajaran bahasa Indonesia sehingga dapat dimanfaatkan pada kegiatan pembelajaran di masa yang akan datang. Penelitian Libiawati dkk tersebut lebih ditekankan kepada kebutuhan bahan ajar menulis teks eksplanasi, sedangkan penelitian ini difokuskan kepada kebutuhan bahan ajar pada masa pandemic Covid-19 bagi mahasiswa.

Pada kegiatan pembelajaran bahan ajar memegang peranan yang utama. Bagi seorang guru/dosen di suatu sekolah atau universitas penggunaan bahan ajar yang tepat dapat membantu guru/dosen dalam proses pembelajaran. Salah satunya dapat menghemat waktu dalam mengajar dan dapat mengubah peran pendidik dari seorang pengajar menjadi fasilitator, serta dapat meningkatkan proses pembelajaran menjadi lebih efektif dan interaktif. Bagi mahasiswa bahan ajar dapat membantu mahasiswa untuk menjadi pembelajar yang mandiri dan dapat digunakan untuk mengukur kompetensi yang telah dikuasai.

Bahan ajar dalam proses pembelajaran perlu diperhatikan dengan baik, karena di dalam proses pembelajaran yang berlangsung selama ini mahasiswa belum memiliki bahan ajar yang sama, dan digunakan sebagai pegangan dalam proses pembelajaran yang dapat mempermudah proses pembelajaran. Mahasiswa memperoleh materi pembelajaran selain dari internet, dari peraturan perundang-undangan dan buku teks. Oleh karena itu, bahan ajar yang diberikan harus sesuai dengan peraturan perundang-undangan dan sesuai dengan kebutuhan mahasiswa di dalam proses pembelajaran. Seorang guru/dosen masih memegang peranan utama sebagai sumber pembelajaran, bahan ajar yang dirancang perlu diperhatikan dengan baik. Bahan ajar yang memiliki mutu yang tinggi dapat memudahkan mahasiswa dalam memahami materi pembelajaran dan dapat dijadikan sebagai pedoman bagi guru/dosen serta mahasiswa di dalam pembelajaran.

Bahan ajar/materi pembelajaran merupakan suatu bahan yang disajikan dosen untuk diolah dan kemudian dipahami oleh mahasiswa, dalam rangka mencapai tujuan instruksional yang telah ditetapkan. Dengan kata lain, bahan ajar merupakan salah satu unsur atau komponen yang penting, artinya untuk mencapai tujuan-tujuan pengajaran bahan ajar terdiri dari faktafakta, generalisasi, konsep, hukum atau aturan, yang terkandung dalam mata pelajaran. Di samping bahan ajar, komponen lain yang perlu dikembangkan dalam rangka mencapai tujuantujuan instruksional adalah kegiatan belajar mengajar. Tanpa adanya kegiatan belajar mengajar yang tepat, sulit bagi mahasiswa untuk dapat memahami materi/bahan ajar yang telah disediakan. Kegiatan belajar mengajar ini mencakup baik kegiatan dosen maupun kegiatan mahasiswa yang perlu diwujudkan dalam setiap pengajaran untuk dapat mencapai tujuan-tujuan instruksional yang telah ditetapkan. Tujuan penelitian ini adalah untuk mengetahui kebutuhan bahan ajar bagi mahasiswa dalam proses pembelajaran di era pandemi ini. Dengan diketahuinya apa yang mahasiswa butuhkan terhadap bahan ajar di era pendemi ini.

\section{LANDASAN TEORI}

Analisis kebutuhan penelitian ini dilihat dari sudut pandang pengajaran yaitu bahan ajar, model pembelajaran, dan evaluasi pembelajaran. Analisis kebutuhan merupakan faktor penting yang harus ditemukan dan dinegosiasikan dalam program pengajaran bahasa. Analisis kebutuhan merupakan penelitian baru di bidang pengajaran bahasa (Astika, 1999). Analisis kebutuhan bahan ajar belum pernah dilakukan sebelumnya, namun ada beberapa penelitian serupa, yaitu sebagai berikut. Analisis kebutuhan bahan ajar belum pernah dilakukan sebelumnya. Namun ada beberapa penelitian serupa, yaitu sebagai berikut. Analisis Kebutuhan bahan ajar IPA Terpadu (Asrizal, Festiyed, \& Sumarmin, 2017). Analisis Kebutuhan Bahan 
Ajar Matematika (Rahmadani, Roza, \& Murni, 2018). Berbeda dengan penelitian sebelumnya, penelitian analisis kebutuhan ini lebih difokuskan pada analisis kebutuhan bahan ajar bahasa Indonesia pada era pendemi covid-19.

Bahan ajar merupakan salah satu komponen yang memegang peranan penting dalam proses pembelajaran. Menurut Ardiansyah dkk (2016) bahan ajar merupakan salah satu komponen yang dapat membantu kelancaran belajar siswa maupun mahasiswa. Bahan ajar adalah segala bentuk bahan yang digunakan untuk membantu guru/instruktor dalam melaksanakan kegiatan belajar mengajar di kelas (Prastowo, 2012).

Menurut Howard \& Major (2004) bahan ajar merupakan bagian penting dari sebagian besar program pengajaran bahasa Inggris. Dari buku teks, kaset video dan gambar ke Internet, guru sangat bergantung pada beragam bahan untuk mendukung pengajaran mereka dan pembelajaran siswa mereka. Menurut Nurjaya (2015) bahan ajar merupakan "subject matter". Bahan ajar yang saat itu sering disebut materi pelajaran dikatakan sebagai suatu kebulatan pengetahuan yang tersusun secara sistematis dari satuan-satuan materi pelajaran. Pandangan modern justru menganggap materi pelajaran bukanlah tujuan. Bahan ajar adalah alat dan media yang memberi peluang kepada siswa untuk memperoleh pengalaman belajar. Melalui bahan ajar guru akan lebih mudah dalam mengajar dan akan lebih mudah membantu siswa dalam belajar. Bahan ajar dapat dimanfaaatkan oleh guru dan siswa untuk memperbaiki pembelajaran. Bahan ajar memiliki posisi amat penting dalam pembelajaran.

Sumber belajar (media) merupakan salah satu komponen yang sangat penting dalam kegiatan pembelajaran. Seperti halnya dijelaskan dalam Undang-Undang No. 20 Tahun 2003 pasal 1 ayat 20 tentang Sistem Pendidikan Nasional bahwa, "pembelajaran adalah proses interaksi peserta didik dengan pendidik dan sumber belajar pada suatu lingkungan belajar". Pengembangan buku ajar di sekolah perlu memperhatikan karakteristik siswa dan kebutuhan siswa sesuai kurikulum, yaitu menuntut adanya partisipasi dan aktivasi siswa lebih banyak dalam pembelajaran. Bahan ajar dalam bentuk buku ajar matematika berpendekatan kontekstual dirancang untuk mempermudah siswa dalam memahami materi, aktif dalam proses pembelajaran, dan dapat menciptakan suasana pembelajaran yang menarik.

\section{METODE PENELITIAN}

Metode Penelitian ini adalah penelitian kualitatif deskriptif. Populasi penelitian adalah seluruh mahasiswa STKIP PGRI Sumbar program studi Pendidikan Bahasa dan Sastra Indonesia yang disebar mulai dari semester satu sampai semester delapan. Populasi penelitian berjumlah 106 orang mahasiswa. Teknik pengumpulan data dilaksanakan dengan cara membagikan link google form yang berisi angket analisis kebutuhan mahasiswa terhadap bahan ajar di era covid-19 yang dapat diakses dengan mudah secara online. Instrumen pengumpulan data yang digunakan adalah lembar angket analisis kebutuhan mahasiswa terhadap bahan ajar yang diberikan melalui Whatsapp Group. Angket dibuatkan dalam google form yang dapat diakses mahasiswa dengan mudah untuk mengisi tanggapan-tanggapan mengenai kebutuhan mahasiswa terhadap bahan ajar di era pandemi covid-19. Penelitian ini bertujuan untuk mengetahui kebutuhan mahasiswa terhadap bahan ajar selama proses pembelajaran daring. Analisis data dilakukan secara deskriptif dengan cara mendeskripsikan hasil angket sesuai dengan indikator penelitian. Data disajikan dengan diagram dan gambar kemudian dideskripsikan hasil jawaban dari diagram atau gambar tersebut.

\section{PEMBAHASAN}

Berdasarkan hasil penelitian selama perkuliahan daring diperoleh poin-poin penting terkait analisis kebutuhan mahasiswa terhadap bahan ajar di era pandemi. Hasil penelitian dipaparkan mulai dari karakteristik informan hingga pembahasan berdasarkan literatur yang 
relevan dengan berbagai aspek yang diteliti. Faktor-Faktor yang menggambarkan kebutuhan mahasiswa terhadap bahan ajar di era pandemi penulis paparkan sebagai berikut.

\section{Bahan Ajar yang Sesuai dengan Kondisi Pandemi}

1) Bahan Ajar yang Dibutuhkan Mahasiswa

Berdasarkan hasil tanggapan mahasiswa, tentang analisis kebutuhan mahasiswa terhadap bahan ajar di era pandemi, bahan ajar yang dibutuhkan mahasiswa yaitu: $72,5 \%$ memberikan tanggapan bahwa bahan ajar yang dibutuhkan mahasiswa yaitu bahan ajar yang disediakan dosen dari e-learning, 12,7\% memberikan tanggapan bahwa bahan ajar yang dibutuhkan mahasiswa yaitu bahan ajar yang dikirim melalui WA Group, dan beberapa mahasiswa lainnya memilih bahan ajar dari youtube, bahan ajar yang dicari sendiri dan bahan ajar yang dicetak. Dari diagram lingkaran di atas dapat disimpulkan bahwa mahasiswa lebih membutuhkan bahan ajar yang disediakan oleh dosen dari e-learning.

Mahasiswa kurang menginginkan materi yang dikirim melalui WA Group, karena materi tersebut bisa terhimpit oleh chat (pembicaraan) lainnya di WAG tersebut. Jika bahan ajar tersebut hilang, mahasiswa kesulitan untuk mencarinya kembali. Kemudian, dari hasil pengisian angket bisa dilihat bahwa mahasiswa lebih cepat memahami sebuah bahan ajar jika bahan ajar tersebut diberikan oleh dosen melalui e-learning lalu mengunduh dan mencetaknya. Tidak terlalu banyak mahasiswa yang langsung membaca dari handphone atau laptop bahan ajar tersebut, karena selain membuat mata jenuh terlalu lama melihat layar, mereka akan mudah mengarsipkan bahan ajar dan melihat secara cepat apabila sewaktu-waktu mereka membutuhkan, mahasiwa sudah jarang mendapatkan bahan ajar dengan mencari, meminjam atau membelinya di toko bukua apalagi di era pandemi seperti ini.

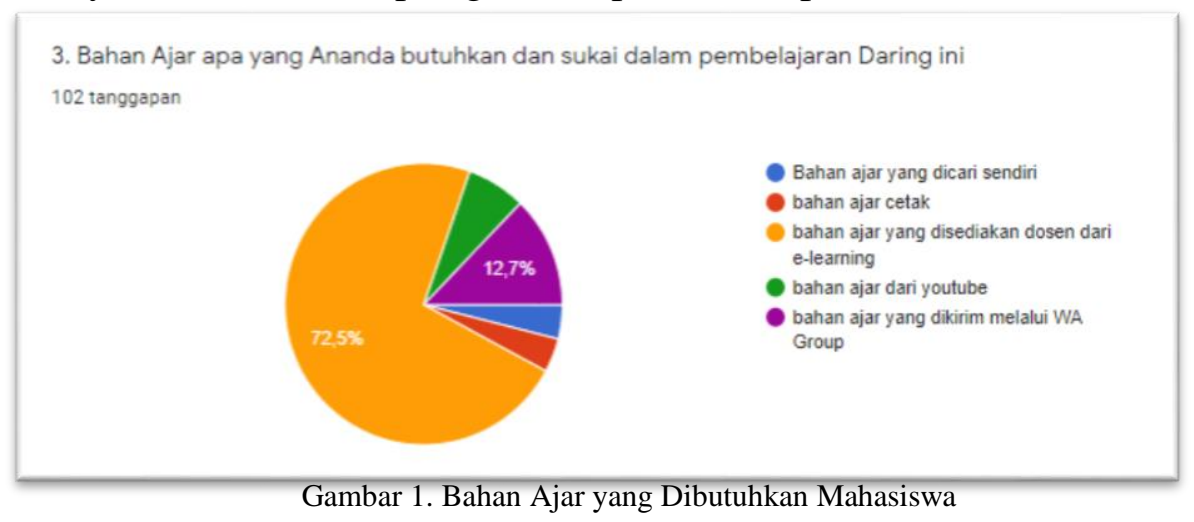

2) Bahan Ajar yang Dimiliki Saat Pembelajaran Daring

Berdasarkan hasil tanggapan mahasiswa tentang analisis kebutuhan mahasiswa terhadap bahan ajar di era pandemi pada faktor bahan ajar yang dimiliki saat pembelajaran daring yaitu: $99 \%$ mahasiswa memberikan tanggapan mengenai bahan ajar yang dimiliki saat pembelajaran daring yaitu bahan ajar yang disediakan dosen dari e-learning, 46,5\% memberikan tanggapan mengenai bahan ajar yang dimiliki yaitu bahan ajar yang dikirim melalui WA oleh dosen, 37,6\% mahasiswa memberikan tanggapan mengenai bahan ajar yang dimiliki yaitu bahan ajar dari youtube, 36,6\% mahasiswa memberikan tanggapan bahwa mereka memiliki bahan ajar yang dicari sendiri. Dari diagram tersebut dapat disimpulkan bahwa mahasiswa banyak memiliki bahan ajar saat pembelajaran daring diperoleh dari dosen pengampu pelajaran yang dimasukkan ke e-learning.

Mahasiswa membutuhkan bahan ajar yang disediakan oleh dosen dari e-learning, melalui e-learning mereka bisa melihat tampilan materi tiap minggu dan sudah tersusun materi dari pertemuan pertama hingga pertemuan terakhir, kemudian melalui e-leraning jika bahan 
ajar tersebut hilang, mereka bisa mengakses kapan saja dan di mana saja dari e-learning kembali.

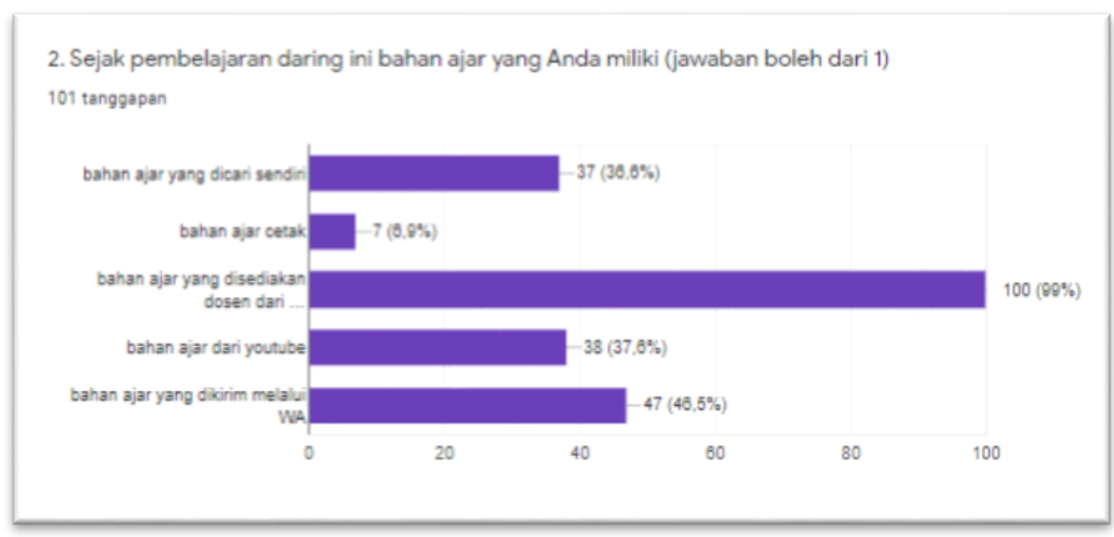

Gambar 2. Bahan Ajar yang Dimilki saat Pembelajaran Daring

\section{3) Bahan Ajar yang Mudah Dipahami}

Berdasarkan hasil tanggapan mahasiswa tentang analisis kebutuhan mahasiswa terhadap bahan ajar di era pandemi pada faktor cara memperoleh bahan ajar agar mudah dipahami yaitu: 60,8 \% mahasiswa memberikan tanggapan bahwa cara mendownload bahan ajar dari e-learning lalu memprintnya/mencetakknya, 55,9\% mahasiswa memberikan jawaban yaitu bahan ajar yang dibaca melalui hp atau laptop, 10,8\% mahasiswa memberikan tanggapan bahwa bahan ajar yang mudah untuk dipahami yaitu meminta dari dosen melalui email, 2\% mahasiswa memberikan jawaban tentang bahan ajar yang mudah dipahami yaitu bahan ajar yang dibeli di toko buku atau membeli buku sendiri. Dari diagram di atas dapat disimpulkan bahwa mahasiswa lebih cepat memahami sebuah bahan ajar jika bahan ajar tersebut diberikan oleh dosen melalui e-learning lalu mengunggah serta memprint/mencetaknya.

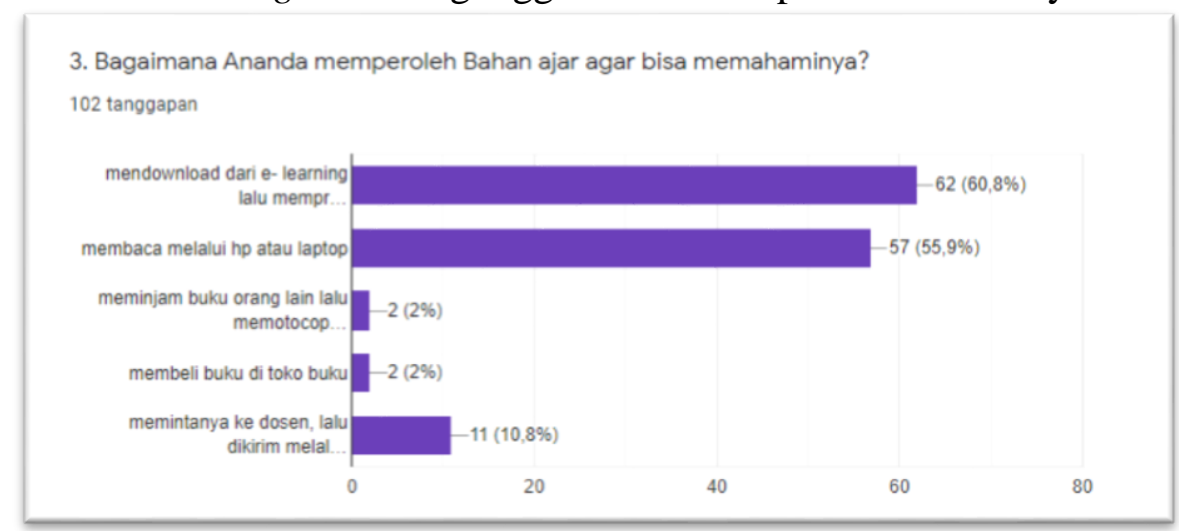

Gambar 3. Bahan Ajar yang Mudah Dipahami

4) Bahan Ajar yang Paling Disukai

Berdasarkan hasil tanggapan mahasiswa tentang analisis kebutuhan mahasiswa terhadap bahan ajar di era pandemi pada faktor jenis bahan ajar yang paling disukai yaitu: $84,3 \%$ mahasiswa memberikan jawaban mengenai jenis bahan ajar yang paling disukai saat pembelajaran daring yaitu jenis bahan ajar berupa modul, 7,8\% mahasiswa memberikan jawaban mengenai bahan ajar yang disukai adalah dari buku ajar, dan beberapa mahasiswa lainnya memberikan jawaban mengenai bahan ajar yang paling disukai yaitu buku teks, lembar kerja, handout dan artikel, dapat disimpulkan bahwa bahan ajar yang paling disukai oleh mahasiswa saat pembelajaran daring yaitu berupa modul. Hal ini bisa disebabkan karena di 
dalam modul terdapat materi yang lengkap dan soal latihan yang lengkap pula. Mereka kurang menyukai bahan ajar yang berupa buku teks, lembar kerja hand out, artikel dan lain sebagainya.

\section{Penyajian Bahan Ajar}

1) Penyajian Materi yang Diharapkan

Berdasarkan hasil tanggapan mahasiswa tentang analisis kebutuhan mahasiswa terhadap bahan ajar di era pandemi covid 19 pada faktor penyajian materi yang diharapkan yaitu : 65,7 \% mahasiswa memberikan jawaban mengenai menyajian materi yang diharapkan yaitu dijalaskan dengan menggunakan media visual, audio dan audio visual, $51 \%$ mahasiswa memberikan jawaban tentang penyajian yang diharapkan yaitu diberikan penjelasan langsung terhadap materi pembelajaran, 44,1\% mahasiswa memberikan jawaban mengenai penyajian yang diharapkan yaitu pembelajaran yang diarakan untuk menemukan konsep, $41 \%$ mahasiswa memberikan jawaban mengenai penyajian yang diharapkan yaitu diberikan contoh-contoh yang dekat dengan mahasiswa, 27,5\% mahasiswa memberikan jawaban mengenai penyajian yang diharapkan yaitu dengan cara dosen menyajikan sebuah masalah terlebih dahulu sebelum masuk ke materi. Dari diagram di atas dapat disimpulkan bahwa mahasiswa lebih mengharapkan penyajian pembelajaran yang menggunakan media pembelajaran.

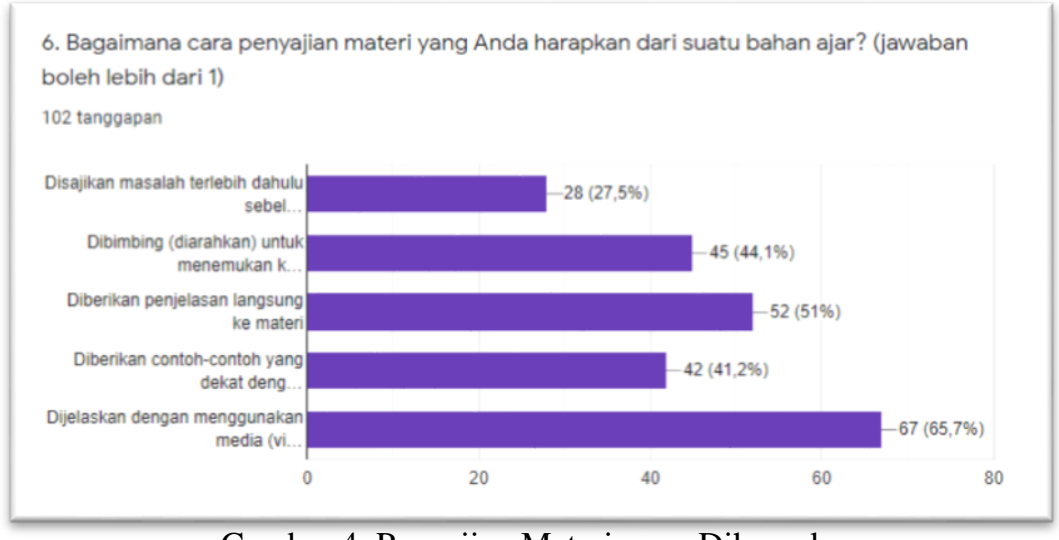

Gambar 4. Penyajian Materi yang Diharapkan

\section{2) Tampilan (Lay Out) yang Disukai}

Berdasarkan hasil tanggapan mahasiswa tentang analisis kebutuhan mahasiswa terhadap bahan ajar di era pandemi covid 19 pada faktor tampilan (Lay Out) yang disukai yaitu: $71,6 \%$ mahasiswa memberikan jawaban tentang tampilan yang disukai yaitu penyajian dalam bentuk power point yang lengkap dengan penjelasan dosen, 38,2\% mahasiswa memberikan jawaban mengenai tampilan yang disukai yaitu disajikan dengan tampilan yang mendalam dan rinci atau lengkap, 25,5\% mahasiswa memberikan jawaban mengenai tampilan yang disukai yaitu tampilan yang disajikan dengan ringkas, 24,5\% mahasiswa memberikan jawaban mengenai tampilan yang disukai yaitu disajikan dengan gambar-gambar yang menarik dan berwarna, 5,9\% mahasiswa memberikan jawaban tentang tampilan yang disukai yaitu berupa desain sederhana, tanpa gambar dan hitam putih saja. Berdasarkan diagram di atas dapat disimpulkan bahwa mahasiswa lebih menyukai tampilan power point yang lengkap dengan penjelasan dosen. Power point yang dijelaskan oleh dosen membuat mereka paham dan mengerti tentang bahan pembelajaran, dibandingkan dengan hanya power point tanpa suara. Beberapa mahasiswa juga menyukai bahan ajar tampilan yang mendalam, rinci, lengkap, menarik dan sedikit berwarna atau bervariasi.

3) Penggunaan Bahasa yang Digunakan Dosen saat Menjelaskan Bahan Ajar 
Berdasarkan hasil tanggapan mahasiswa tentang analisis kebutuhan mahasiswa terhadap bahan ajar di era pandemi covid 19 pada faktor penggunaan bahasa yang digunakan dosen yaitu: 89,2,7\% mahasiswa memberikan jawaban bahwa mereka menyukai penggunaan gaya bahasa baku, tapi tidak kaku dari sebuah bahan ajar, $10.8 \%$ mahasiswa menjawab bahwa mereka menyukai penggunaan gaya bahasa tidak baku dari sebuah bahan ajar. Maka dapat disimpulkan bahwa bahwa mahasiswa menyukai penggunaan gaya bahasa baku, tapi tidak kaku dari sebuah bahan ajar. Hal ini disebabkan, karena mahasiswa menyadari bahwa sebuah bahan ajar merupakan karya tulis ilmiah yang bahasanya memang harus baku. Mahasiswa menginginkan bahan ajar yang menggunakan bahasa baku, tapi tidak terlalu kaku.

\section{Kendala Mahasiswa dalam Pembelajaran}

1) Kesulitan yang Ditemukan Saat Mempelajari Bahan Ajar

Berdasarkan hasil tanggapan mahasiswa tentang analisis kebutuhan mahasiswa terhadap bahan ajar di era pandemi pada faktor kesulitan yang ditemukan saat mempelajari bahan ajar yaitu: pertama, jika ada materi yang masih belum dipahami akan sulit untuk menjawab soalnya dan tidak ada juga modulnya, serta ada yang tidak dijelaskan sama sekali materi pelajaran. Kedua, kesulitan dalam jaringan/signal. Ketiga, kesulitan dalam mengambil bahan ajar di e-learning kadang tidak bisa dibuka. Keempat, kesulitan dalam kuota internet. Kelima, kesulitan memahami penjelasan materi yang kurang lengkap. Maka dapat disimpulkan bahwa mahasiswa kesulitan dengan materi pembelajaran yang belum lengkap, sulit dipahami serta terbatas oleh jaringan internet.

2) Kesulitan dalam Memenuhi Kebutuhan Materi yang Dibutuhkan Mahasiswa

Berdasarkan hasil tanggapan mahasiswa tentang analisis kebutuhan mahasiswa terhadap bahan ajar di era pandemi covid 19 pada faktor apakah bahan ajar sudah sesuai kebutuhan yaitu: 43,1\% mahasiswa memberikan jawaban mengenai apakah bahan ajar sudah sesuai dengan kebutuhan, mahasiwa menjawab cukup memenuhi, 31,4\% mahasiswa memberikan jawaban mengenai apakah bahan ajar sudah sesuai kebutuhan mahasiswa menjawab memenuhi, 14,7\% mahasiswa memberikan jawaban kurang memenuhi, 10,8\% mahasiswa menjawab sangat memenuhi. Berdasarkan diagram di atas dapat disimpulkan bahwa bahan ajar cukup memenuhi kebutuhan mahasiswa terhadap bahan ajar.

\section{PENUTUP}

Pada kegiatan pembelajaran bahan ajar memegang peranan yang utama. Bagi seorang guru/dosen penggunaan bahan ajar yang baik dan tepat dapat membantu guru/dosen dalam proses pembelajaran. Hasil penelitian dari analisis kebutuhan mahasiswa terhadap bahan ajar yaitu: pertama, mahasiswa membutuhkan bahan ajar yang disediakan oleh dosen dari $e$ learning. Kedua, mahasiswa lebih cepat memahami sebuah bahan ajar jika bahan ajar tersebut diberikan oleh dosen melalui e-learning lalu mengunduh dan memprintnya. ketiga, mahasiswa lebih menyukai tampilan power point yang lengkap disertai penjelasan dosen, keempat, mahasiswa menyukai penggunaan gaya bahasa baku, tapi tidak kaku dari sebuah bahan ajar. kelima, bahan ajar yang selama ini diberikan dosen saat pembejaran daring cukup memenuhi kebutuhan namun belum maksimal, keenam, bahan ajar yang diberikan dosen saat pembelajaran daring cukup relevan/sesuai dengan topik, ketujuh, kebutuhan mahasiswa terhadap bahan ajar sangat tinggi di era covid-19 ini. Ini menunjukkan bahwa mahasiswa membutuhkan informasi yang lebih detail tentang pelajaran dalam rangka mendapatkan pemahaman yang mendalam. 


\section{DAFTAR PUSTAKA}

Ardiansyah, R., Corebima, A. D., \& Rohman, F. (2016). Analisis Kebutuhan Pengembangan Bahan Ajar Perubahan Materi Genetik pada Matakuliah Genetika di Universitas Negeri Malang. Seminar Nasional Pendidikan Dan Saintek 2016, 2016, 1.

Asrizal, A., Festiyed, F., \& Sumarmin, R. (2017). Analisis Kebutuhan Pengembangan Bahan Ajar Ipa Terpadu Bermuatan Literasi Era Digital Untuk Pembelajaran Siswa Smp Kelas Viii. Jurnal Eksakta Pendidikan (Jep), 1(1), 1. https://doi.org/10.24036/jep/vol1-iss1/27

Astika, G. (1999). The Role of Needs Analysis in English for Specific Purposes. TEFLIN Journal, 10(1), 31-47. https://doi.org/10.15639/teflinjournal.v10i1/31-47

Howard, J., \& Major, J. (2004). Guidelines for designing effective English language teaching materials. 9th Conference of Pan Pacific Associatio. 101-109. Retrieved from http://www.paaljapan.org/resources/proceedings/PAAL9/pdf/Howard.pdf

Libiawati, D., Indihadi, D., \& Nugraha, A. (2020). Analisis Kebutuhan Penyusunan Buku Ajar Mata Pelajaran Bahasa Indonesia Berbasis Menulis Teks Eksplanasi. PEDADIDAKTIKA: Jurnal Ilmiah Pendidikan Guru Sekolah Dasar, 7(2), 77-82.

Mallu, S., \& Samsuriah. (2020). Implementasi articulate storyline dalam pembuatan bahan ajar digital pada stmik profesional Makassar. Prosiding Seminar Nasional Teknik Elektro Dan Informatika (SNTEI) 2020, 7.

Marbun, P. (2021). Disain Pembelajaran Online Pada Era Dan Pasca Covid-19. CSRID (Computer Science Research and Its Development Journal), 12(2), 129. https://doi.org/10.22303/csrid.12.2.2020.129-142

Mustofa, M. I., Chodzirin, M., \& Sayekti, L. (2019). Formulasi Model Perkuliahan Daring Sebagai Upaya Menekan Disparitas Kualitas Perguruan Tinggi (Studi terhadap Website pditt.belajar.kemdikbud.go.id). Walisongo Journal of Information Technology, 1(2), 151160. https://doi.org/10.21580/wjit.2019.1.2.4067

Nurjaya, G. (2015). Pengembangan Bahan Ajar Metode Pembelajaran Bahasa Dan Sastra Indonesia Berbasis Pembelajaran Kooperatif Jigsaw Untuk Meningkatkan Pemahaman Dan Kemampuan Aplikatif Mahasiswa. JPI (Jurnal Pendidikan Indonesia), 1(2), 102111. https://doi.org/10.23887/jpi-undiksha.v1i2.4490

Prastowo, A. (2012). Panduan Kreatif Membuat Bahan Ajar Inovatif. Yogyakarta: Diva Press. Rahmadani, H., Roza, Y., \& Murni, A. (2018). Analisis Kebutuhan Bahan Ajar Matematika Berbasis Teknologi Informasi di SMA IT Albayyinah Pekanbaru. JURING (Journal for Research in Mathematics Learning), 1(1), 91. https://doi.org/10.24014/juring.v1i1.5230

Rusdiana, A., Sulhan, M., Arifin, I. Z., \& Kamludin, U. A. (2020). Penerapan Model POE2WE Berbasis Blended Learning Google Classroom Pada Pembelajaran Masa WFH Pandemic Covid-19. Scientific Writing of the Bandung State Islamic University 2020, 1-10. 